\title{
TU/e EmonONEN

\section{Quality control of histamine and methacholine in diagnostic solutions with capillary electrophoresis}

\section{Citation for published version (APA):}

Schans, van der, M. J., Reijenga, J. C., \& Everaerts, F. M. (1996). Quality control of histamine and methacholine in diagnostic solutions with capillary electrophoresis. Journal of Chromatography, A, 735(1-2), 387-393. https://doi.org/10.1016/0021-9673(95)00721-0

DOI:

10.1016/0021-9673(95)00721-0

Document status and date:

Published: 01/01/1996

\section{Document Version:}

Publisher's PDF, also known as Version of Record (includes final page, issue and volume numbers)

\section{Please check the document version of this publication:}

- A submitted manuscript is the version of the article upon submission and before peer-review. There can be important differences between the submitted version and the official published version of record. People interested in the research are advised to contact the author for the final version of the publication, or visit the $\mathrm{DOI}$ to the publisher's website.

- The final author version and the galley proof are versions of the publication after peer review.

- The final published version features the final layout of the paper including the volume, issue and page numbers.

Link to publication

\section{General rights}

Copyright and moral rights for the publications made accessible in the public portal are retained by the authors and/or other copyright owners and it is a condition of accessing publications that users recognise and abide by the legal requirements associated with these rights.

- Users may download and print one copy of any publication from the public portal for the purpose of private study or research.

- You may not further distribute the material or use it for any profit-making activity or commercial gain

- You may freely distribute the URL identifying the publication in the public portal.

If the publication is distributed under the terms of Article 25fa of the Dutch Copyright Act, indicated by the "Taverne" license above, please follow below link for the End User Agreement:

www.tue.nl/taverne

Take down policy

If you believe that this document breaches copyright please contact us at:

openaccess@tue.nl

providing details and we will investigate your claim. 


\title{
Quality control of histamine and methacholine in diagnostic solutions with capillary electrophoresis
}

\author{
M.J. van der Schans, J.C. Reijenga*, F.M. Everaerts \\ Laboratory of Instrumental Analysis, Eindhoven University of Technology, P.O. Box 513, 5600 MB Eindhoven, Netherlands
}

\begin{abstract}
Solutions of histamine and methacholine bromide in different matrices for diagnostic purposes were analyzed for stability and quality control using capillary electrophoresis. Histamine (2-[4-imidazolyl]ethylamine) [CAS No. 51-45-6] was determined using a $0.1 \mathrm{M}$ Tris-borate buffer of $\mathrm{pH} 8.3$ with $5 \cdot 10^{-5} M$ cetyltrimethylammonium bromide (CTAB) and $0.005 \%$ poly(vinyl alcohol) (PVA) and detected at $214 \mathrm{~nm}$ using clenbuterol [4-amino- $\alpha$ (tert.-butylaminomethyl)-3,5-dichlorobenzyl alcohol] [37148-27-9] as an internal standard. Metacholine bromide (acetyl- $\beta$-methacholine bromide) [333-31-3] was determined with a $0.01 \mathrm{M}$ creatinine-chloride buffer of $\mathrm{pH} 4.85$ and detected with indirect UV at $230 \mathrm{~nm}$ using potassium as an internal standard. Histamine solutions were stable for a prolonged period of time, whereas under enforced degradation conditions methacholine was hydrolyzed, yielding acetic acid and (tentatively) $\beta$-methylcholine as reaction products.
\end{abstract}

Keywords: Capillary electrophoresis; Quality control; Histamine; Metacholine

\section{Introduction}

Allergic reactions are developed by one in every six individuals in industrialized countries [1]. For the treatment of different kinds of allergies, a number of solutions containing allergenic extracts are used. In an earlier study [2], capillary isotachophoresis was used as a qualitative technique to monitor the (glyco)protein profile of allergenic extracts, e.g. from pollen or house dust mites. Samples were dialyzed prior to analysis in order to remove low-molecular-mass components.

Prior to treatment with the above-mentioned allergenic extracts, specifically for diagnostic pur-

* Corresponding author. poses, the skin response to intracutaneous injections of solutions of histamine and methacholine is often determined in order to obtain valuable qualitative (and sometimes semi-quantitative) information with regard to allergic response in general and that in which especially histamine plays a crucial role [3]. Mostly these solutions also contain buffering substances. With respect to the consistency of the information obtained from their use, short- and long-term stabilities of these solutions are of prime importance. In the present study, capillary zone electrophoresis was used as a routine quantitative method for the quality control of diagnostic solutions of histamine and metacholine and, in addition, to monitor the thermal degradation of these solutions in dependence of their initial matrix composition. 


\section{Experimental}

\subsection{Equipment}

All measurements were carried out on a Beckman P/ACE 2200 capillary electrophoresis instrument (Beckman Instruments, Fullerton, CA, USA). A fused-silica capillary of $75 \mu \mathrm{m}$ I.D., 330 $\mu \mathrm{m}$ O.D. was purchased from Scientific Glass Engineering (Milton, Keynes, UK). Operating conditions were: voltage, $20 \mathrm{kV}$; sample introduction was performed with pressure injection for $10 \mathrm{~s}$ at $33 \cdot 10^{2} \mathrm{~Pa}$. Prior to each injection, the capillary was rinsed at $1.3 \cdot 10^{5} \mathrm{~Pa}$ for $1 \mathrm{~min}$ with $0.1 \mathrm{M} \mathrm{HCl}$, for $1 \mathrm{~min}$ with $0.01 \mathrm{M} \mathrm{KOH}$, and for 2 min with buffer. Buffers were prepared from analytical grade reagents (Merck, Darmstadt, Germany), dissolved in Milli-Q purified water (Millipore, Bedford, MA, USA). The data were collected on a personal computer and analyzed by the program CAESAR V3.0 (CE Solutions, Long Branch, NJ, USA).

\subsection{Chemicals}

All chemicals needed for the electrolyte systems were purchased from Merck (Darmstadt, Germany), with the exception of poly(vinyl alcohol) (PVA) which was from Hoechst (Frank- furt, Germany). Histamine and methacholine standards were provided by HAL (Haarlem Allergenen Laboratorium, Haarlem, Netherlands).

\subsection{Sample solutions}

Samples were provided as aqueous solutions in 3 or $5 \mathrm{ml}$ ampules (HAL). These solutions contained a number of other components (e.g. for stabilization purposes) such as phenol, monobasic sodium phosphate, dibasic sodium phosphate, $\epsilon$-aminocaproic acid ( $\epsilon$-ACA), glycerol, and human serum albumin. The samples and standard solutions were diluted with distilled water and internal standard solution on mass basis.

\subsection{Histamine analysis}

The capillary was $57 \mathrm{~cm}$ long $(50 \mathrm{~cm}$ to the detector), the detection wavelength was $214 \mathrm{~nm}$. A higher wavelength of detection resulted in an insufficient signal-to-noise ratio. The electrophoresis buffer was $0.1 M$ Tris-borate $\mathrm{pH} 8.3$ with $5 \cdot 10^{-5} M$ cetyltrimethylammonium bromide (CTAB) and $0.005 \%$ poly(vinyl alcohol) (PVA; Hoechst, Frankfurt, Germany) (Table 1). The

Table 1

Operational systems for the analysis of diagnostic solutions of histamine (system A) and methacholine (systems B and C)

\begin{tabular}{|c|c|c|c|}
\hline Parameter & System A & System B & System C \\
\hline Capillary length, overall (mm) & 570 & 870 & 870 \\
\hline Length to detector (mm) & 500 & 800 & 800 \\
\hline I.D. $(\mu \mathrm{m})$ & 75 & 75 & 75 \\
\hline O.D. $(\mu \mathrm{m})$ & 330 & 330 & 330 \\
\hline Buffer co-ion & $0.1 M$ Tris & $0.01 M$ creatinine & $0.01 M$ histidine \\
\hline Buffer counter-ion & borate & $\mathrm{HCl}$ & phthalic acid \\
\hline Buffer pH & 8.3 & 4.85 & 5.3 \\
\hline Additives & $\begin{array}{l}5 \cdot 10^{-5} M \text { CTAB } \\
0.005 \% \text { PVA }\end{array}$ & none & $5 \cdot 10^{-5} M$ CTAB \\
\hline Polarity & positive & positive & negative \\
\hline Voltage (kV) & 20 & 20 & 20 \\
\hline Detection wavelength (nm) & 214 & 230 , indirect & 230 , indirect \\
\hline
\end{tabular}

Tris = Tris(hydroxymethyl)aminomethane $\quad[77-86-1] ; \quad$ CTAB $=$ cetyltrimethylammonium bromide $[57-09-0] ;$ PVA = poly $($ vinyl alcohol) [CAS No. 9002-89-5]. 
concentration of histamine in the sample solutions ranged between $1 \mu \mathrm{g} / \mathrm{ml}$ and $50 \mathrm{mg} / \mathrm{ml}$.

\subsection{Methacholine bromide analysis}

The capillary was $87 \mathrm{~cm}$ long $(80 \mathrm{~cm}$ to the detector). As the component of interest does not show UV absorption, detection was carried out at $230 \mathrm{~nm}$ in the indirect mode, using creatinine as the UV-absorbing buffer co-ion. For this reason, a background electrolyte of $0.01 M$ creatinine$\mathrm{HCl}, \mathrm{pH} 4.85$, was used. As an internal standard potassium was used which also shows a negative peak in the indirect mode of detection (see Table 1). The concentration of methacholine bromide in the sample solutions ranged between 0.1 and $20 \mathrm{mg} / \mathrm{ml}$.

\section{Results and discussion}

\subsection{Histamine analysis}

For histamine, a $1 \mathrm{~g} / 1$ histaminediphosphatemonohydrate stock solution in water was made. This was diluted on a mass basis with water and a $0.5 \mathrm{~g} / 1$ clenbuterol solution. Final concentrations were between 0.1 and $0.8 \mathrm{~g} / \mathrm{l}$ for histamine and $0.06 \mathrm{~g} / 1$ for clenbuterol. Calibration graphs thus obtained had correlation coefficients of 0.9995 or better. Samples were diluted in a comparable way to give concentrations within the corresponding calibration range.

Histamine could be detected by its native absorption. In order to improve the inter-variation, a cationic internal standard was required with UV absorbance at $214 \mathrm{~nm}$ and an effective mobility lower than $25 \cdot 10^{-9} \mathrm{~m}^{2} \mathrm{~V}^{-1} \mathrm{~s}^{-1}$. Clenbuterol was found to be a suitable candidate. Although histamine $\left(\mathrm{p} K_{\mathrm{a}} \mathrm{s} 5.94\right.$ and 9.75) is positively charged over a broad $\mathrm{pH}$ range, analysis at $\mathrm{pH} 8.3$ is preferred because of two reasons. Although at neutral $\mathrm{pH}$ the difference in mobility between histamine and sodium, which is also present in the samples, is considerable, the sodium zone is a broad triangle with a sloping front because of the low effective mobility of the buffer co-ion [4]. The UV absorbance at $214 \mathrm{~nm}$ of the sodium zone is due to a local increase of the counter-ion concentration (borate). The steep rear boundary of the sodium consequently migrates at a considerably lower mobility, and it should be baseline resolved from the histamine peak. This is achieved by analyzing at a $\mathrm{pH}$ somewhat closer to the $\mathrm{p} K_{\mathrm{a}}$ of the histamine. Initial experiments without additives to the background electrolyte showed insufficient resolution between sodium and histamine (Fig. 1a). This was caused by considerable electroosmosis, directed towards the detector, a problem often encountered when analyzing cations at high $\mathrm{pH}$. This can be seen from the well-known resolution equation $[5,6]$ :

$R_{\mathrm{s}}=\frac{1}{4 \sqrt{2}} \Delta \mu \sqrt{\frac{V L_{\mathrm{d}}}{D L_{\mathrm{t}}\left(\mu_{\mathrm{av}}+\mu_{\mathrm{eo}}\right.}}$

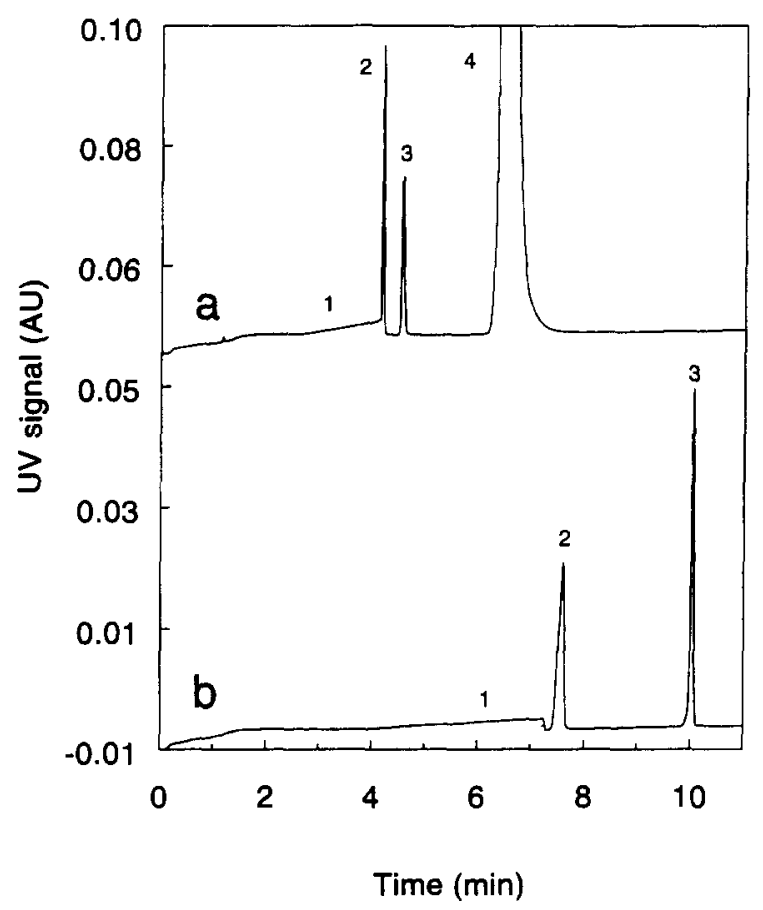

Fig. 1. Typical analysis of a diagnostic solution of histamine, using system A (Table 1) without additives (a) and with PVA and CTAB as additives (b). Peaks: $1=$ sodium, $2=$ histamine, $3=$ clenbuterol (I.S.), and $4=$ phenol. 
in which $R_{\mathrm{s}}$ is the resolution, $\Delta \mu$ the difference in effective mobility, $V$ the voltage, $L_{\mathrm{d}}$ the length to the detector, $D$ the average diffusion coefficient, $\mu_{\mathrm{av}}$ the average effective mobility, $L_{\mathrm{t}}$ the total capillary length, and $\mu_{\mathrm{eo}}$ the electroosmotic mobility. Although the difference in effective mobility $\Delta \mu$ is significant, the electroosmotic mobility $\mu_{\mathrm{eo}}$, with the same sign as $\mu_{\mathrm{av}}$, is considerable, resulting in a low resolution (Fig. 1a).

Addition of $5 \cdot 10^{-5} M$ CTAB and $0.005 \%$ PVA effectively suppresses electroosmosis [7], even at the relatively high $\mathrm{pH}$ of the background electrolyte used. The result is a better resolution with the same mobility difference $\Delta \mu$ (Fig. 1b).

The efficiency of the histamine peak is lower (apparent plate numbers 88000 and 21000 , respectively) because part of the isotachophoretic (ITP) stacking is lost, but the resolution between histamine and sodium is much better, in accordance with Eq. 1.

Figs. $1 \mathrm{a}$ and $1 \mathrm{~b}$ also show that, is that in spite of the fact that clenbuterol reaches the detector much later with suppressed electroosmosis, its peak height is larger. This can be explained by a reduction of the solute-wall interactions caused by the CTAB-PVA combination. The efficiency of the clenbuterol peak is much higher (apparent plate numbers 40000 and 130000 , respectively).

To correct for the drift in migration time, the peak areas of both the separand and the internal standard can be divided by the migration times. Calibration graphs thus obtained are often slightly better than those obtained without such correction. Such a correction is especially useful in cases where run-to-run fluctuations of the electroosmotic flow are encountered. In general, the correction is based on a constant linear velocity of each sample component during analysis.

However, in the case of histamine analysis in a system with suppressed electroosmosis, the migration time of especially histamine, but also of the internal standard, depends on the sodium content in the sample. This is caused by the fact that in the initial stage of separation an isotachophoretic configuration is present due to the mobility sequence sodium $>$ histamine $>$ clenbuterol $>$ Tris. This is clearly visualized in Fig. 2,

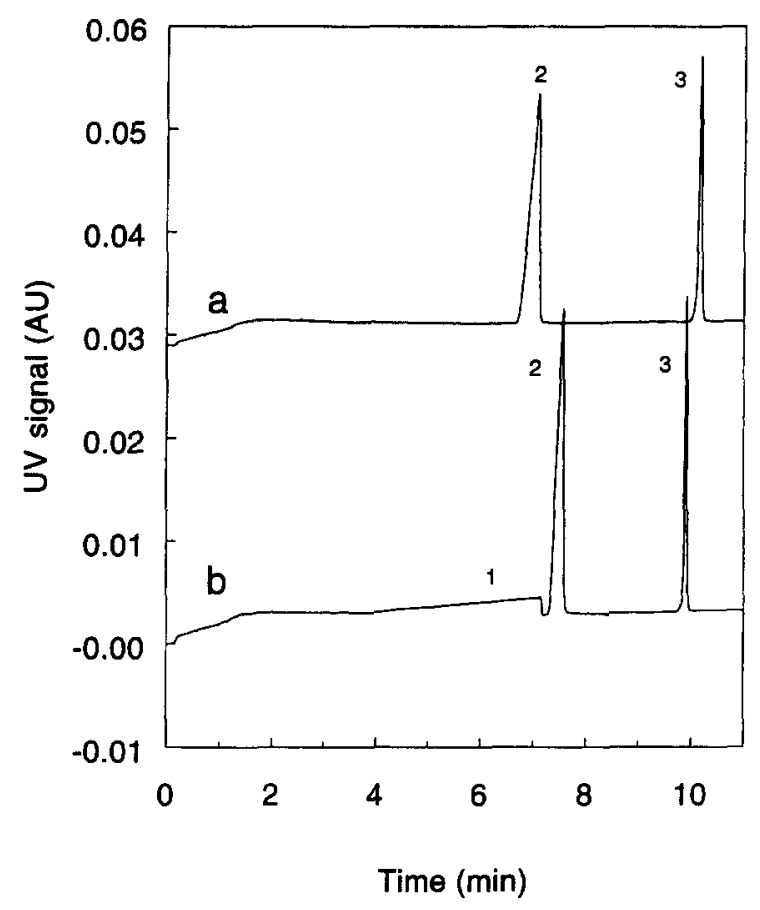

Fig. 2. Comparison of the analysis of histamine in the absence (a) and in the presence (b) of sodium, using system A (Table 1) with PVA and CTAB as additives. Sample component numbers as in Fig. 1.

where Fig. 2a shows the analysis without sodium. Comparison with the analysis of a sample with sodium (Fig. 2b) shows that both the histamine and the clenbuterol peak have significantly higher efficiencies caused by initial ITP stacking, as expected [4]. Apparent plate numbers increase from 8600 to 14000 for histamine and from 135000 to 236000 for clenbuterol. The migration times, however, show a shift that cannot be attributed to electroosmosis. From Fig. $2 b$ it is obvious that a considerable part of the capillary contains sodium. The histamine peak comes later because histamine was forced to migrate at a lower field strength due to the presence of sodium. Clenbuterol, however, moves faster, due to a higher field strength in the part of the capillary not containing sodium. In this case it was found that correction of the (relative) peak areas with migration times does not lead to improved recovery. Thus, in the case of ITP stacking, migration time correction for relative 
peak area determination is not advised, unless standards and samples have the same matrix and consequently the same stacking behavior.

In an inter-variation assay for histamine, the following errors were included: weighing, pipetting, deviation of calibration curve, matrix effects, analytical separation, detection, and integration. The results are summarized in Table 2 . Recoveries between 90 and $98 \%$ were achieved with a $2 \%$ relative standard deviation (R.S.D.) at the $10 \mathrm{mg} / \mathrm{ml}$ concentration level.

\subsection{Methacholine analysis}

For methacholine bromide, a $0.5 \mathrm{~g} / \mathrm{l}$ stock solution in water was made. This was diluted on a mass basis with water and a $1 \mathrm{~g} / \mathrm{l} \mathrm{KCl}$ solution. Final concentrations for the calibration solutions were between 0.064 and $0.45 \mathrm{~g} / 1$ for methacholine bromide and $0.1 \mathrm{~g} / 1$ for $\mathrm{KCl}$.

Calibration graphs thus obtained were linear within the concentration range mentioned. The coefficients of correlation were at least 0.9995 . Samples were diluted in a comparable way to give concentrations within the corresponding calibration range.

Methacholine migrates as a cation at acidic $\mathrm{pH}$ but it does not show any UV absorption. Therefore it was decided to perform detection in the indirect UV mode. A buffering cation with UV absorption was found in creatinine. A $0.01 M$ creatinine solution was buffered with $\mathrm{HCl}$ at the $\mathrm{p} K_{\mathrm{a}}$ value of creatinine: 4.85 . As seen in a typical analysis (Fig. 3a), separation from bulk sodium content is satisfactory. As an internal standard, potassium was used for the following reasons: it has no UV absorption, was absent in all samples,

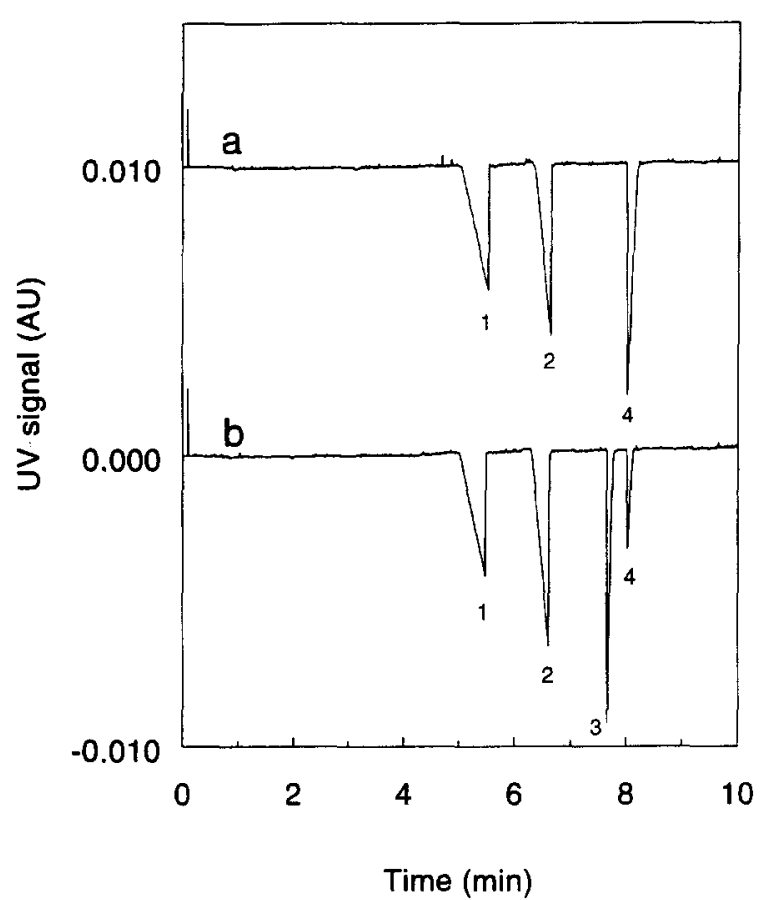

Fig. 3. Typical analysis of a diagnostic solution of methacholine, using system B (Table 1). A fresh solution (a) was compared with a degraded solution (b). Peaks: $1=$ potassium (I.S.), 2 = sodium, 3 = degradation product (probably $\beta$ methylcholine), and $4=$ methacholine.

and has a mobility of $76.2 \cdot 10^{-9} \mathrm{~m}^{2} \mathrm{~V}^{-1} \mathrm{~s}^{-1}$ and so migrates sufficiently ahead of sodium.

The results of an inter-variation assay for methacholine, including all aforementioned experimental errors, are summarized in Table 3. Recoveries between 98.6 and $100 \%$ were achieved with a $2 \%$ R.S.D. at the $10 \mathrm{mg} / \mathrm{ml}$ concentration level.

A number of samples with different matrices were stored for several months at different

Table 2

Inter-variation assay of the analysis of histamine

\begin{tabular}{|c|c|c|c|}
\hline Concentration $(\mathrm{mg} / \mathrm{ml})$ & Matrix & Recovery (\%) & R.S.D. of recovery \\
\hline 10 & phenol-water & 98 & \\
\hline 10 & phenol-Na-phosphate- $\epsilon$-ACA-water & 98 & $2 \%(n=9)$ \\
\hline 0.1 & phenol-Na-phosphate- $\epsilon$-ACA-water & 90 & \\
\hline 0.003 & phenol-Na-phosphate-e-ACA-water & 91 & \\
\hline
\end{tabular}


Table 3

Inter-variation assay of the analysis of methacholine

\begin{tabular}{|c|c|c|c|}
\hline Concentration $(\mathrm{mg} / \mathrm{ml})$ & Matrix & Recovery (\%) & R.S.D. of recovery \\
\hline 10 & phenol-Na-phosphate- $\epsilon$-ACA-water & 100 & $2 \%(n=8)$ \\
\hline 1 & phenol-Na-phosphate- $\epsilon$-ACA-water & 98.6 & \\
\hline 0.1 & phenol-Na-phosphate- $\epsilon$-ACA-water & 100 & \\
\hline
\end{tabular}

temperatures. An example of enforced degradation (24 months at room temperature) of a methacholine solution is shown in Fig. 3b. An additional peak is observed, whereas the peak area of methacholine, relative to that of the internal standard, is decreased. The effective mobility of the additional peak, calculated with sodium as a mobility reference, was $32.5 \cdot 10^{-9}$ $\mathrm{m}^{2} \mathrm{~V}^{-1} \mathrm{~s}^{-1}$. It was suspected that hydrolysis of methacholine results in the formation of acetic acid (not visible in the cationic analysis) and $\beta$-methylcholine. The latter component was not

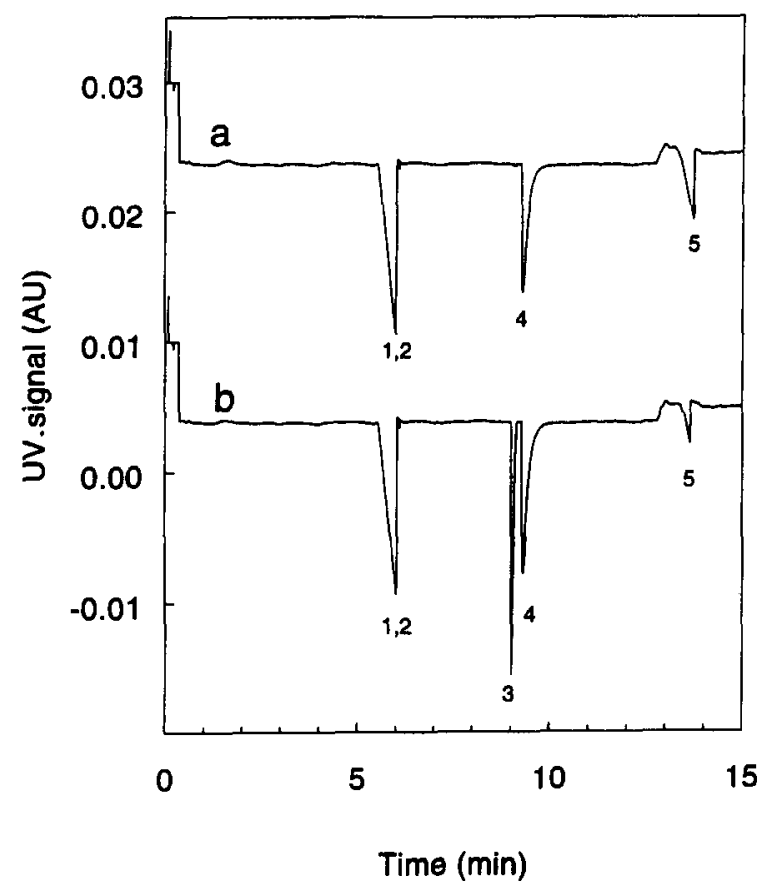

Fig. 4. Forced degradation of a methacholine solution, using anionic system C (Table 1); a fresh solution (a) versus a degraded solution (b). Peaks: $1=$ chloride (from I.S.), $2=$ bromide, $3=$ acetate (degradation product), $4=$ phosphate, $5=$ system peaks. available, but the effective mobility of choline under the operational conditions used appeared to be $36 \cdot 10^{-9} \mathrm{~m}^{2} \mathrm{~V}^{-1} \mathrm{~s}^{-1}$, so that the peak of $32.5 \cdot 10^{-9} \mathrm{~m}^{2} \mathrm{~V}^{-1} \mathrm{~s}^{-1}$ might very well be $\beta$ methylcholine, the additional methyl group accounting for the mobility difference.

Hydrolysis of methacholine to acetic acid and $\beta$-methylcholine was suspected. In order to verify this degradation reaction, additional anionic analysis of the above-mentioned samples was carried out. Acetate has to be analyzed with indirect UV as well, using electrolyte system C (Table 1). The results are shown in Fig. 4. In Fig. $4 a$, an anionic analysis is shown of a fresh methacholine solution, corresponding to the cationic analysis in Fig. 3a. The chloride (from the internal standard) and bromide peaks (from the buffer and the sample) coincide, which was verified with separate injections of pure $\mathrm{KCl}$ and $\mathrm{KBr}$, respectively. In addition there is a phosphate peak (sample) and system peaks, originating from analyzing the chloride/bromide combination in a twin co-ion buffer: phthalate/bromide [8]. No acetic acid is detected in the fresh sample. Fig $4 \mathrm{~b}$ shows an anionic analysis of the sample corresponding to Fig. $3 \mathrm{~b}$. The migration time of the additional peak corresponds to the migration time of acetate. Consequently, the proposed hydrolysis reaction into $\beta$-methylcholine and acetic acid is very likely.

\section{Conclusions}

Capillary zone electrophoresis has proved to be a fast and flexible tool for monitoring quality control of diagnostic solutions of histamine and methacholine. Long-term stability of solutions is easily monitored: forced degradation of methacholine showed hydrolysis into acetic acid and 
(tentatively) $\beta$-methylcholine, whereas histamine solutions were stable under these conditions.

\section{Acknowledgement}

Financial support and provision of samples for this study by HAL (Haarlem Allergenen Laboratorium, Haarlem, Netherlands) are gratefully acknowledged.

\section{References}

[1] B. Weeke, Allergy, 38 (1983) 529.

[2] C.H.M.M. de Bruyn, J.C. Reijenga, G.V.A. Aben, Th.P.E.M. Verheggen and F.M. Everaerts, J. Chromatogr., $320(1985) 205$.
[3] M.A. Beaven, in P. Dukor, P. Kallós, Z. Trnka, B.H. Waksman and A.L. de Weck (Editors), Histamine: Its Role in Physiological and Pathological Processes, Monographs in Allergy, Vol. 13, Karger, Basel, 1978.

[4] F.E.P. Mikkers, F.M. Everaerts and Th.P.E.M. Verheggen, J. Chromatogr., 169 (1979) 1.

[5] S.F.Y. Li, Capillary Electrophoresis, J. Chromatogr. Library, Vol. 52, Elsevier, Amsterdam, 1992.

[6] J. Vindevogel and P. Sandra, Introduction to Micellar Electrokinetic Chromatography, Hüthig, Heidelberg, 1992.

[7] Th.P.E.M. Verheggen and F.M. Everaerts, J. Chromatogr., 638 (1993) 147.

[8] J.L. Beckers, J. Chromatogr. A. 679 (1994) 153. 